\title{
Tax alters telomerase activity through both quantitative and qualitative hTERT transcriptional dysregulations
}

\author{
Maroun Karam", Morgan Thenoz ${ }^{1}$, Linda Zane ${ }^{2}$, Céline Vernin ${ }^{1}$, Agnes Lançon $^{3}$, Christiane Pinatel ${ }^{3}$, Eric Wattel', \\ Franck Mortreux ${ }^{1 *}$
}

From 15th International Conference on Human Retroviruses: HTLV and Related Viruses

Leuven and Gembloux, Belgium. 5-8 June 2011

In untransformed cells impaired for DNA damage repair such as Tax positive cells, insufficient telomerase activity (TA) triggers tumorigenic telomere dysfunctions. Here we show that in quiescent HTLV-1+ T cells deriving from carriers, hTERT expression paralleled tax expression, suggesting that Tax promotes an immortalized phenotype in quiescent $\mathrm{T}$ cells. Interestingly, PHA-stimulation significantly augmented tax expression in CD4 $+(2.6$ times, $\mathrm{p}=0.022)$ but not in CD8 $+\mathrm{T}$ cells $(1.3$, ns). 48 hours after PHA stimulation, uninfected and HTLV-1+CD8 + cells augmented their TA and hTERT expression ( $\mathrm{p}<0.03$ for each). In contrast PHA possessed no significant effect on TA and hTERT in HTLV-1 + CD4+ cells. The PHA-induced fold changes in TA and hTERT expression were respectively 22 and 6.9 -folds lower in infected than in uninfected CD4+ T cells, indicating that PHA decreased the level of TA more than 3 folds that of hTERT expression in the sole HTLV-1 $+\mathrm{CD} 4+\mathrm{T}$ cells subset. This hiatus between hTERT expression and TA was reproduced in vitro upon ectopic Tax expression in epithelial cells. We thus supposed that upon PHA-dependent Tax expression, a negative post-transcriptional element targeted hTERT for decreasing TA in HTLV $-1+C D 4+$ T cells. Accordingly we next demonstrated that, beside its repressive effect on the hTERT promoter, ectopic Tax expression strongly redistributed hTERT RNA isoforms towards a significantly increased proportion in inactive isoforms and a significantly decreased proportion in the active $\mathrm{A}$ $+B+$ isoform. Thus via Tax expression, naturally HTLV-

\footnotetext{
* Correspondence: franck.mortreux@ens-lyon.fr

'Oncovirologie et Biotherapies, UMR5239 CNRS/ENS Lyon/UCBL/HCL, Hopital Pierre Benite, Lyon, France

Full list of author information is available at the end of the article
}

1 infected CD4+ T cells undergo both transcriptional and post-transcriptional hTERT modifications that significantly decrease TA in vivo.

\section{Author details}

'Oncovirologie et Biotherapies, UMR5239 CNRS/ENS Lyon/UCBL/HCL, Hopital Pierre Benite, Lyon, France. ${ }^{2}$ Laboratory of Molecular Microbiology, National Institute of Allergy and Infectious Diseases, the National Institutes of Health, Bethesda, Maryland 20892, USA. ${ }^{3}$ Oncovirologie et Biotherapies, Centre Léon Bérard, Lyon, France.

Published: 6 June 2011

doi:10.1186/1742-4690-8-S1-A131

Cite this article as: Karam et al:: Tax alters telomerase activity through both quantitative and qualitative hTERT transcriptional dysregulations. Retrovirology 2011 8(Suppl 1):A131.

Submit your next manuscript to BioMed Central and take full advantage of:

- Convenient online submission

- Thorough peer review

- No space constraints or color figure charges

- Immediate publication on acceptance

- Inclusion in PubMed, CAS, Scopus and Google Scholar

- Research which is freely available for redistribution

\section{Biomed Central}

(c) 2011 Karam et al; licensee BioMed Central Ltd. This is an open access article distributed under the terms of the Creative Commons Attribution License (http://creativecommons.org/licenses/by/2.0), which permits unrestricted use, distribution, and reproduction in any medium, provided the original work is properly cited. 